\title{
Demystifying Science Teachers' Epistemic Belief on Chemical Concepts: Students' Engagement in the School Garden
}

\author{
Kamal Prasad Acharya ${ }^{1 *}$ \\ ${ }^{1}$ Department of Science and Environmental Education, Central Department of Education, Tribbuvan University, Kirtipur, \\ Kathmandu, NEPAL
}

*Corresponding Author: kamalacharya@tucded.edu.np

Citation: Acharya, K. P. (2019). Demystifying Science Teachers' Epistemic Belief on Chemical Concepts: Students' Engagement in the School Garden. Pedagogical Research, 4(4), em0044. https://doi.org/10.29333/pr/5943

Published: September 28, 2019

\begin{abstract}
The purpose of the study was to transforming chemistry learning from the textbooks in the silent classrooms to the school garden through activity-based learning with students' meaningful engagement in collaboration with the science teachers in the community schools in Nepal. This research also aims to clarifying the epistemological gridlocks (banking concept of education) of school science teachers through measuring $\mathrm{pH}$ of garden soil samples by the basic level students' activities. The concern of this study was facilitating school science teachers to impart the practical knowledge of chemical concept ( $\mathrm{pH}$ of soil) by simple experiments whose backup is based on the epistemologically Vedic education system in Nepal. In-depth interviews and participant observations were taken with the students and teachers about their epistemic beliefs of teaching and learning the basic chemical concepts of chemistry based on the basic level science curriculum. It is found that the science teachers' positivist congestions were rooted in the dogmatic approach in chemistry teaching and hinders the eloquent engagement of students in the school gardening activities. Science teachers' belief system enabled me to understand the positivist epistemology mindset and transform into play way chemistry learning in the school garden. This broader sphere of teachers' beliefs enabled me to recognize why positivist epistemology and connected traditions linking activity-based chemistry learning superficially forceful in the community schools. It is recommended that the suggestions for the school teacher professional improvement are needed to supervise and facilitate them to clarify the reflections on their situated personal experiences.
\end{abstract}

Keywords: chemical concept, epistemic belief, meaningful engagement, $\mathrm{pH}$, school garden

\section{INTRODUCTION}

School science reforms in almost all parts of the world support a view of teaching and learning chemical concepts that highlights activity-based instruction and meaningful engagement of students and teachers in practical activities (Marx et al., 2004; Sawada et al., 2002; Wallace and Louden, 1992; Van Driel, Beijaard and Verloop, 2001). However, research reveals that practices of developing scientific inquiry through hands-on activities in schools do not reflect such an engagement (Beach, 2019; Hand, Park and Suh, 2018; Sullivan and Puntambekar, 2019). One of the major concerns is that basic level science teachers in the schools of Nepal show epistemological immature understandings about basic chemical concepts through school gardening activities (Acharya, 2016, 2019).

Taking into consideration the basic level science teachers hold in demonstrating the performs of classroom activities in the silent environment to recite the chemical concepts, the anticipated transformation in school science based on science teachers' capability to assimilate the theory and hands-on activities of a reform with their opinions 
and current practices (Holstermann, Grube and Bögeholz, 2010; Satterthwait, 2010). However, in an overview of science teachers' beliefs in chemical education, Hamilton concludes that experienced science teachers have belief sets that are stable, closely held, and resistant to change. Thus, the desired change put forward by reforming the curricula keeping emphasis on scientific inquiry and engagement of students meaningfully in the school gardening activities. This study follows in that understanding how teachers' beliefs concerning activity-based chemistry learning from the school garden intersect with factors such as local context and teachers' epistemic beliefs, we can better inform our approaches to reform learning chemistry at the basic level schools in Nepal. Thus, in this article I seek to explore science teachers' beliefs about the application of school garden and how they connect with various beliefs concerning teaching and learning in a situated practice of developing scientific thinking.

The place of leaving for this study was participatory action research (Acharya et al., 2018) where the students, teachers and $I$ as a co-researcher were engaged in a series of dialogue conferences, formal and informal conversations and collaborating with the school head teacher at the basic level school to learn from and develop a practice of logical investigation of chemical concepts for learning chemistry from the school gardening activities.

For exploring the purpose of the study, I collaborated with the basic level science teachers who have been teaching at the school science for ten years, which had implemented the application of the school garden for developing the basic skills of learning chemistry in the second cycle of participatory action research (PAR). In the second cycle of the PAR, I observed and analyzed the skills and techniques applying to teach chemistry (eg. $\mathrm{pH}$ ) and found that it represented a simplified and the traditional approach of delivering the lectures. In this connection, researchers argue that teachers followed the sequential method and little use of theory to inform the students' inquiries (Glover, Harrison and Shallcross, 2018; Mamlok-Naaman et al., 2018). Teachers changed their styles of teaching chemistry reflecting a more contemporary view on activity-based instruction after the engagement in a series of workshops, professional development programmes, dialogue conferences, and conversations during this cycle. Orientations of the teachers were messy before starting the intervention. However, this "unsuccessful" attempt leads me to ask questions about why they wanted changes were not realized even though the teacher planned for and positively valued them. Even though there are likely other reasons why the desired changes did not occur after teaching and learning for more than ten years, this motivated me to understand more about the teachers' epistemic beliefs about school gardening activities in the situated school context.

The rationale for this research is that in order to explore why beliefs about activity-based science learning through school gardening activities are tough to change. I used in-depth semi-structured interviews and classroom observations with the science teachers in the chemistry portion for a month to identify the teachers' beliefs concerning activity-based instruction.

The study is guided by two research questions:

1. What are the basic level science teachers' beliefs concerning activity-based chemistry learning?

2. How do these beliefs change over time (six month period during the second cycle of PAR) with the scope of activity-based science learning through school gardening activities?

The following review provides background and theoretical framework for the article. I address relevant research concerning teacher beliefs about school gardening activities for chemistry learning and teaching as a complex and uncertain enterprise.

\section{Science Teachers' Belief on Activity-based Chemistry Learning}

Exploring the science teachers' opinions can offer understandings into the forms of capabilities that science tutors (teachers' dictate) deliver in their classes/laboratories. In a review of the science teachers' beliefs (Acharya, 2017) "reported that opinions are peculiar ideas that intensely affect peoples" performance and that the belief system has an adaptive function in helping individuals define and understand the world themselves".

Researches like (Grenier, 2018; Louca et al., 2018; Thomson et al., 2018) have investigated teachers' beliefs concerning activity-based instruction and it appears that a positivist ideology is commonly held among science teachers. Actually, a positivist view of activity-based science instruction (ABSI) can take the shape of either immature inductive learning (learning from example to the major concepts) or immature deductive learning (moving from big ideas to examples). According to (Acharya, 2017) there is research suggesting a congruency between teachers' beliefs about ABSI and their classroom activities, while other show no significant associations between science educators' understanding of activity-based chemistry learning. Question whether standardized tests for assessing teachers' conceptions about gardening activities and logical investigation is effective to explain the documented discontinuation between teachers' adopted views and classroom practice of ABSI (Acharya, 2016).

Meaningful engagement starts with the activity-based instruction in the school garden. My assumption as a coresearcher in participatory action research is that action and understanding are the foundation for knowledge creation. Experiencing by collaboration is not knowledge but is a constitutive component of understanding. School garden experiences need to be conveyed by some sort of dissection into practice, an inquiry that pursues to frame meaning and judgments and that leads to attentive action (Acharya, 2019). 
This write up seeks to inquire how school education collaborate teachers for the change in classroom teaching and learning activities to (i) contribute to their learning by engaging in the school garden and (ii) co-create knowledge in action through school gardening activities. In crafting the responses to this inquiry, we (I as a coresearcher, students and the science teachers) adopted two approaches: learning through action and participatory action research. Participatory action research through garden activities is a methodological approach which motivates basic level students to learn science by doing and activity-based learning became an instructional strategy that comprises students working and reflecting together on concrete learning condition. In this reflection as a part of PAR, we explore how action learning accomplishes the cycle of PAR based on the objective of converting experience into practical learning. It accomplishes the cycle of engaging in research based on experience to cocreate knowledge.

Science teachers apply empirical practices to pretend everyday working experiences. Such counterfeit actions often referred to as pragmatic learning, can be pretty effective in giving learners a flavor for the use of thoughts in action. I was one of the co-researchers in PAR process; I was connecting the knowledge of garden activities at science classes in the basic level community schools. This applies "a constructivist view of learning, stipulating that the purpose of teaching is not to transmit information but to encourage knowledge formation and development (Barak, 2017; Duit, 2016; Wallace and Brooks, 2015). When given generous freedom to engage in self-discovery with others, students enthusiastically create the essential information to make insight of their environment (Acharya, 2017; Glover, Harrison and Shallcross, 2018; Hand, Park and Suh, 2018).

\section{MATERIALS AND METHODS}

\section{Research Design}

Qualitative research design based on an interpretive paradigm in a naturalistic understanding was used in this study. Based on this design, this study concentrated on obtaining gorgeous and comprehensive explanations of case studies of two basic level science teachers' changes in their teaching practices according to activity-based instruction by the application of the school garden to learn chemistry through the participatory action research.

\section{Method}

The participatory action research study was significant in six months in the second cycle of my $\mathrm{PhD}$ study related to school gardening activities for understanding basic chemistry concepts, as a part of science teachers' professional development programme. This cycle was related to activity-based science learning through school gardening activities. During the time of six months, first, this research enabled me to get acquainted with both the practices and the dogmatic beliefs of the science teachers and the second, the deficiency of improvement in the teacher's practices stimulated our interest in understanding the scope and force of the beliefs articulated by the teacher. I chose semi-structured interviews as a means to let the teacher speak more freely about the activity-based school gardening instruction and classroom observations. Furthermore, the meaning was related to their own practice in the science classroom.

\section{Research Participants}

The participants in this study were two basic level science teachers of a community school in Nepal. These two case studies were purposefully selected based on three criteria: 1 ) the teachers teaching science for more than ten years; 2) they were interested in understanding the challenges and solution of dogmatic belief system through activity-based science learning; and 3) they experienced problems in the classroom related to chemistry teaching. Surya and Nandu were the pennames apportioned to the two case studies selected to study the influence of classroom participatory action research on the application of activity-based chemistry learning through school gardening activities.

\section{Data Collection}

During the second cycle of the PAR, I was engaged with both the basic level science teachers, observed the classes, sharing experiences with them in formal and informal conversations, and during the school gardening activities especially in measuring $\mathrm{pH}$ of soil samples. Collaboration in this study involved the activities related to activity-based chemistry learning with the cooperating teachers, students and I as a co-researcher in PAR, worked together to improve science teaching skills based on the draft education policy of the Ministry of Education (MoE) Nepal Government "One Garden One School' programme. Collaboration in this study involved five steps: (a) identifying problems from the teachers' teaching experiences; (b) discussing ways to solve those problems; (c) designing lessons to implement activity-based chemistry instruction; (d) implementing the ideas of gardening 




Figure 1. Changes teachers' belief by students' activities

activities; (d) reflecting on their chemistry lesson delivery practices; and (e) demystifying the dogmatic beliefs of science teachers through the school gardening activities.

I observed teachers' pedagogical styles; listen to their priorities in the classrooms, a basic understanding of chemical concepts, students' activities during class hours, conducted interviews and reviewed students' note copies. Each case study was involved participants with data collection through semi-structured interviews conducted with the researchers both at the beginning and again towards the end of each gardening activity during the second cycle of PAR. Each data source was required to be combined with different data sources in order to enhance the validity and crosschecking of the findings via triangulation. I used informal interviews of approximately 20-30 minutes in length for the clarification and facilitating analysis, validity checks, and triangulation.

\section{Data Analysis}

To analyze the cases, I used an interpretive design that was derived from Erickson (2012). Firstly, the data were transcribed all semi-structured interviews and performed an open coding using the software ATLAS.ti for qualitative analysis, searching the data for interesting features relevant to the purpose of the research (ibid). Secondly, I performed an analysis where the first step was collecting codes into potential themes (e.g. activitybased chemistry learning through gardening activities). The within-case analysis was conducted using the constant comparative method. The data analysis process for the constant comparative method consisted of four steps: comparing incidents applicable to each category; integrating categories and their properties; delimiting the theory, and reducing and refining the categories and their properties. After finishing the within-case analysis, a cross-case analysis was used to make comparisons across the two cases. The researcher read and summarized the relevant themes that emerged with respect to each participant. Similarities and differences were identified based on the research questions. Finally, scrutinizing the themes I found three emerging dimensions of the science teacher's beliefs concerning school gardening activities and the situated practice of scientific concepts: (1) hands-on activities are the ways to motivate students and oppose rote learning; (2) school garden is the source of curiosity as well as knowledge source and (3) scientific inquiry as a simple step-by-step method. The results of the analysis are presented in the forms of narratives connected to each of the three dimensions to convey the belief that was implicit in the stories of the teacher. I also present obnoxious proclamations concerning their views. Finally, I made a conceptual map to make explicit the teacher's beliefs as revealed through the narratives and to make visible the relationships between his beliefs (Figure 1).

\section{RESULTS}

The findings from the data analysis presented according to the research questions.

\section{Finding 1: Heavily loaded minds-on activities}

Learning chemistry at the basic level schools in Nepal is mostly rote-learning and reproduces the textbook knowledge. Students and the teachers both want to recite the facts, figures, chemical notations and equations in the name of understanding the basic chemical concept. Teaching and learning are totally based on the narration of 
Table 1. Types of indicators used

\begin{tabular}{ccccccccccc}
\hline Groups & A & B & C & D & E & F & G & H & I & J \\
\hline Method & \multicolumn{2}{c}{ Red cabbage extract } & & Vinegar test & & & PH paper test & \\
\hline Soil samples & 1 & 2 & 3 & 4 & 5 & 6 & 7 & 8 & 9 \\
\hline Result & alkaline & alkaline & acidic & alkaline & acidic & alkaline & alkaline & acidic & acidic & acidic \\
\hline
\end{tabular}

Table 2. $\mathrm{pH}$ of soil and interpretation

\begin{tabular}{cccccc}
\hline$<5.0$ & $\mathbf{5 . 5}$ & $\mathbf{6 . 0}$ & $\mathbf{6 . 5 - 7 . 5}$ & $\mathbf{7 . 5 - 8 . 5}$ & $>\mathbf{8 . 5}$ \\
\hline Strongly Acidic & Moderately Acidic & Slightly Acidic & Neutral & Moderately Alkaline & Strongly Alkaline \\
\hline None & None & One soil sample & None & Nine soil samples & None \\
\hline
\end{tabular}

Table 3. Science teachers' interpretation of soil $\mathrm{pH}$ and vegetables

\begin{tabular}{ccccc}
\hline pH of soil & $\mathbf{4 . 5 - 6 . 0}$ & $\mathbf{5 . 5 - 7 . 5}$ & $\mathbf{6 . 0 - 7 . 0}$ & $\mathbf{6 . 0 - 7 . 5}$ \\
\hline $\begin{array}{c}\text { Vegetables to } \\
\text { grow }\end{array}$ & \multirow{2}{*}{ Potato } & $\begin{array}{c}\text { Pumpkin, cucumber, cauliflower, } \\
\text { tomato, carrot, eggplant, }\end{array}$ & $\begin{array}{c}\text { Onion, lettuce, corn, } \\
\text { garlic, }\end{array}$ & $\begin{array}{c}\text { Cabbage, spinach, beans, } \\
\text { pumpkin, radish }\end{array}$ \\
\hline
\end{tabular}

science textbooks and notes. The problem with this way of learning is that it hinders the students' creative ideas. Science teachers' beliefs are in accordance with accepting the theory-laden nature of observation, and belief in a fixed cognitive method of learning. Teachers were focusing on transforming the chemical knowledge from the textbook to the students by the use of dictation approach. There was no value of logic in the teaching learning chemistry.

Studies related to classroom practices mainly found classroom delivery are teacher dominated rote learning. Teacher lecturing, drilling, reading and repeating from the textbook, and memorizing questions/answers were the dominant approaches. Another important aspect, the classroom process, which was envisioned to be childcentered, was found largely confined to whole class teaching and leaving the weaker students behind. The result shows that the common classroom teaching and learning practice was the use of the textbook by the teachers more often than the curriculum, even if teacher's guide or other curricular materials are available in the school or could be easily arranged if needed.

\section{Finding 2: Increasing the Meaningful Engagement of Students}

School gardening activities for activity-based chemistry learning of basic level students engaged meaningfully in the garden while measuring the $\mathrm{pH}$ of the garden soil samples. From this engagement, I found that most students worked well together while exploring for information as per the activities. The soil $\mathrm{pH}$ reflects whether soil is acidic, neutral, basic or alkaline. The acidity, neutrality or alkalinity of a soil is measured in terms of hydrogen ion activity of the soil water system. The negative logarithm of the hydrogen ion $\left(\mathrm{H}^{+}\right)$activity is called $\mathrm{pH}$ and thus $\mathrm{pH}$ of a soil is a measure of only the intensity of activity and not the amount of the acid present. The $\mathrm{pH}$ range normally found in varies from 3 to 9 .

Students collected ten soil samples from different places in the school garden construction site. They put samples into ten different beakers and added1/2 cup of vinegar to each soil sample. They observed the fizzes in the soil. They observed that eight soil samples fizzes out, concludes alkaline soil with a pH between 7 and 8 . Two soil samples did not fizz after doing the vinegar test. Students added distilled water to the remaining beakers and two teaspoons of soil. They added half cup baking soda in each beaker. In two beakers, the soil was found acidic. The range of $\mathrm{pH}$ was found between 5 and 6 . None of the soil samples reacts at all indicating that the soil was not neutral. Students were observed with fun while doing activities. These activities raise the enthusiasm and the curiosity of the students.

\section{Red Cabbage Water pH Test}

One group of students in the garden tested the $\mathrm{pH}$ of soil by extracting the juice of red cabbage. Students measured approximately 2 cups of distilled water into a watch glass and added one spoonful of red cabbage extract. Four soil samples found the $\mathrm{pH}$ was 7 to 8 that changes the colour purple. Knowing the $\mathrm{pH}$ of garden soil helped students the first-hand experience.

Hydrangeas respond to the soil $\mathrm{pH}$ where they are planted. They found that the blue soil became acidic $(\mathrm{pH}$ $5.5 \&<5.5$ ), if the soil is highly acidic then the colour become the bluest of blue. Pink flowers are produced in alkaline soil ( $\mathrm{pH} 7 \&>7$ ), if the soil was highly alkaline then the colour of the flower become white.

Mathematically $\mathrm{pH}$ is represented as, $\log 1 / \mathrm{H}=-\log \mathrm{H}^{+}$

\section{Finding 3: Play way science learning approach rectify teachers' dogmatic beliefs}

The dogmatic belief of science teachers to teach chemistry at the basic public school in Nepal has been changed due to garden-based activities. Following narrative reveals how science teachers perceive chemistry was taught in 
the past and how it can be shifted through school gardening activities, and why they provide their students with the opportunity to do activities.

\begin{abstract}
Chemistry teaching in the basic level public is mostly about rote learning and repeating facts. Science teachers depend largely on the textbook and the readymade notes. The problem with this way of learning is that it binders students' enthusiasm and creativity. It is difficult for a teacher to discover the students' potential during the lecture method of teaching. School gardening activities provide us with more opportunities to discover and flourish multiple intelligence of our student.
\end{abstract}

After six month engagement (participation in conversations, workshops and dialogue conferences) with the coresearchers, I do now believe that play way is the best method of teaching and learning chemistry. Now I hope activity-based learning approach makes students free to ask, collaborate and understand the basic chemical concepts. I have experienced that students become more self-confident in chemistry learning through working in the school garden. We believe students' progress is the result of their meaningful engagement in school gardening activities.

Science teachers shared a concern related to chemistry learning as focusing on memorizing facts before starting the second cycle of PAR project at the school. They have changed their opinion of using the lecture method of teaching chemistry to activity-based learning through the school gardening activities. Now, teachers highlight the importance of collaboration and meaningful engagement for students in the school garden. The following narrative reveals that teachers' own epistemological belief changed through the garden activities to provide a common understanding of chemical concepts to the students.

I see the school garden is like an open environment. It provides students and teachers with a pleasure and wonders while learning the basic chemical concept like measuring the $p H$ of soil. Garden is a source of knowledge, and it is essential for us. In my opinion, we find everything in the school garden that is fit for basic level science curriculum. And now we think that science laboratory is not merely necessary to learn such pedagogical concepts. Now, I do believe science is for all and everything can be learnt from the garden which is in the basic level science curriculum. Gardening activities through play way learning is democratic and gives students freedom and possibilities.

This narration of the science teachers show that teachers' belief changed during the period of six months from the dogmatic and epistemic belief to the activity-based instruction of learning chemical concepts through the meaningful engagement of students. The surprising finding of this research is that the power of students' engagement in the school garden supports transforming teachers' belief that upgrades the performance of basic level students.

\title{
DISCUSSION
}

School science teachers hold the contextual and the dogmatic belief about the activity-based chemistry learning through school gardening activities is found in many research literature (Acharya, 2017; Bazzul, Wallace and Higgins, 2018; Gottschalk, 2018; Rowbottom, 2016). As a researcher and a PhD student, my contribution is to show through the research analysis of the reality of basic level science teachers that belief about school gardening activities as "One Garden One School" is the new and emergent concept drafted in education policy in Nepal to meet the sustainable development goal. In the following, it will be discussed the science teachers' beliefs concerning school gardening activities and meaningful engagement of students to understand the basic concept of chemistry, as well as further, discuss how these beliefs represent scope and strength for the teacher in a situated context with low-achieving students. This is my answer to the research questions. Finally, some implications for science teacher education and teacher professional development will be suggested.

The first research question was: What is the basic level science teachers' beliefs concerning activity-based chemistry learning? To sum up the results, the current study has shown that the dogmatic and stereotypic belief was embedded with the science teachers before starting the PAR project in the school. The findings is an indication that teachers' views on the activity-based chemistry learning through school gardening activities was situated that became the main cause of low achievement and understanding of chemistry at the basic level schools in Nepal.

The second research question was: How do these beliefs changed over time with the scope of activity-based science learning through school gardening activities? It is found that the changes in teachers' belief over the period of six months of doing activity-based learning through school gardening activities. Science teachers transformed the epistemological beliefs based on the philosophy of learning by doing as advocated by John Dewey which was argued by. By the scientific method, students are provided with a tool connecting them with natural phenomena. 
In this sense, the activity-based instruction "liberates" students from "lecturing" to "doing". The learning process becomes a matter of a relationship between the students, school garden and the teacher as co-researcher, freed from the social background of the students, earlier experiences of conquest and the context of formal school education.

\section{REFERENCES}

Acharya, K. P. (2016). Fostering critical thinking practices at primary science classrooms in Nepal. Research in Pedagogy, 6(2), 1-7. https://doi.org/10.17810/2015.30

Acharya, K. P. (2017). Science teachers' information processing behaviours in Nepal: A reflective comparative study. Research in Pedagogy, 7(1), 1-6. https://doi.org/10.17810/2015.43

Acharya, K. P. (2019). Inquiry-Based Science Learning Through School Gardening Activities: Wonderful Experience through Participatory Action Research. International Journal of Elementary Education, 7(3), 40-45. https://doi.org/10.11648/j.ijeedu.20180703.11

Acharya, K. P., Devkota, B., Budhathoki, C. B. and Bjonness, B. (2018). Relevance Of Learning Science Through Inquiry Based Participatory Action Research In Basic Public Schools Of Nepal: A Proposal. The Online Journal of New Horizons in Education, 8(4), 87-97.

Aleixandre, M. P. J. and Crujeiras, B. (2017). Epistemic practices and scientific practices in science education. In Science Education (pp. 69-80). Brill Sense. https://doi.org/10.1007/978-94-6300-749-8_5

Barak, M. (2017). Science teacher education in the twenty-first century: A pedagogical framework for technologyintegrated social constructivism. Research in Science Education, 47(2), 283-303. https://doi.org/10.1007/s11165015-9501-y

Bazzul, J., Wallace, M. F. and Higgins, M. (2018). Dreaming and immanence: Rejecting the dogmatic image of thought in science education. Cultural Studies of Science Education, 13(3), 823-835. https:// doi.org/10.1007/s11422-017-9816-2

Beach, R. (2019). Engaging Students in Shared Inquiry. Voices from the Middle, 26(3), 9-13.

Duit, R. (2016). The constructivist view in science education-what it has to offer and what should not be expected from it. Investigaçôes em ensino de ciências, 1(1), 40-75.

Elby, A., Macrander, C. and Hammer, D. (2016). Epistemic cognition in science. In Handbook of epistemic cognition (pp. 125-139). Routledge.

Glover, S. R., Harrison, T. G. and Shallcross, D. E. (2018). Benefits to Secondary School Chemistry Teachers Who Have Brought Their Students to Engagement Activities with a University Chemistry Department for Several Years; Continuing Professional Development by Diffusion?. Acta Didactica Napocensia, 11(1), 117-127. https://doi.org/10.24193/adn.11.1.9

Gottschalk, C. M. C. (2018). Teaching critical thinking: The struggle against dogmatism. Educational Philosophy and Theory, 50(5), 469-477. https://doi.org/10.1080/00131857.2016.1168731

Grenier, M. (2018). Cooperating Teachers' Beliefs and Teaching Practices. ICHPER-SD Journal of Research, 9(2), 20-27.

Hand, B., Park, S. and Suh, J. K. (2018). Examining teachers' shifting epistemic orientations in improving students' scientific literacy through adoption of the Science Writing Heuristic approach. In Global developments in literacy research for science education (pp. 339-355). Springer, Cham. https:// doi.org/10.1007/978-3-319-69197-8_20

Holstermann, N., Grube, D. and Bögeholz, S. (2010). Hands-on activities and their influence on students' interest. Research in science education, 40(5), 743-757. https:// doi.org/10.1007/s11165-009-9142-0

Louca, L., Skoulia, T., Tsivitanidou, O. E. and Constantinou, C. P. (2018). Concluding Remarks: Theoretical Underpinnings in Implementing Inquiry-Based Science Teaching/Learning. In Professional Development for InquiryBased Science Teaching and Learning (pp. 261-280). Springer, Cham. https://doi.org/10.1007/978-3-319-914060_14

Lunn Brownlee, J., Ferguson, L. E. and Ryan, M. (2017). Changing teachers' epistemic cognition: A new conceptual framework for epistemic reflexivity. Educational Psychologist, 52(4), 242-252. https:/ / doi.org/10.1080/00461520.2017.1333430

Mamlok-Naaman, R., Eilks, I., Bodner, G. and Hofstein, A. (2018). Professional development of chemistry teachers (Vol. 1). Royal Society of Chemistry.

Marx, R. W., Blumenfeld, P. C., Krajcik, J. S., Fishman, B., Soloway, E., Geier, R. and Tal, R. T. (2004). Inquiry based science in the middle grades: Assessment of learning in urban systemic reform. Journal of research in Science Teaching, 41(10), 1063-1080. https:// doi.org/10.1002/tea.20039

Rowbottom, D. P. (2016). Indoctrination and science education. Encyclopedia of Educational Philosophy and Theory, 15. https://doi.org/10.1007/978-981-287-532-7_39-1 
Satterthwait, D. (2010). Why are 'hands-on' science activities so effective for student learning?. Teaching Science: The Journal of the Australian Science Teachers Association, 56(2).

Sawada, D., Piburn, M. D., Judson, E., Turley, J., Falconer, K., Benford, R. and Bloom, I. (2002). Measuring reform practices in science and mathematics classrooms: The reformed teaching observation protocol. School science and mathematics, 102(6), 245-253. https://doi.org/10.1111/j.1949-8594.2002.tb17883.x

Sullivan, S. and Puntambekar, S. (2019). Learning with multiple online texts as part of scientific inquiry in the classroom. Computers \& Education, 128, 36-51. https://doi.org/10.1016/j.compedu.2018.09.004

Thomson, M. M., DiFrancesca, D., Carrier, S., Lee, C. and Walkowiak, T. A. (2018). Changes in Teaching Efficacy Beliefs among Elementary Preservice Teachers from a STEM-focused Program: Case Study Analysis. Journal of Interdisciplinary Teacher Leadership (JoITL), 2(1).

Van Driel, J. H., Beijaard, D. and Verloop, N. (2001). Professional development and reform in science education: The role of teachers' practical knowledge. Journal of Research in Science Teaching: The Official Journal of the National Association for Research in Science Teaching, 38(2), 137-158. https://doi.org/10.1002/10982736(200102)38:2<137::AID-TEA1001>3.0.CO;2-U

Wallace, C. S. and Brooks, L. (2015). Learning to teach elementary science in an experiential, informal context: Culture, learning, and identity. Science Education, 99(1), 174-198. https://doi.org/10.1002/sce.21138

Wallace, J. and Louden, W. (1992). Science Teaching and Teachers' Knowledge: Prospects for Reform of Elementary Classrooms. Science Education, 76(5), 507-21. https://doi.org/10.1002/sce.3730760505 